\title{
PLANEJAMENTO FAMILIAR E REPRODUÇÃO ASSISTIDA
}

\section{Raphael Rego Borges Ribeiro*}

Resumo: Neste artigo, estudamos a reprodução assistida enquanto mecanismo de exercício do planejamento familiar. Com base na revisão da literatura especializada, estabelecemos premissas e, usando o método dedutivo, refletimos sobre o objeto de pesquisa. Observamos que o planejamento familiar é garantido na Constituição, na Lei 9263/1996 e no Código Civil. Também notamos que os direitos reprodutivos e sexuais são reconhecidos internacionalmente e nacionalmente. Percebemos que, nascidas para tratar a infertilidade, as técnicas de reprodução assistida hoje são instrumentos de exercício do projeto parental. Concluímos ainda que o Brasil ainda precisa de legislação específica sobre a matéria.

Palavras-chave: Reprodução assistida; planejamento familiar; direito de família; biodireito; direitos reprodutivos.

\section{FAMILY PLANNING AND ASSISTED REPRODUCTION}

Abstract: In this paper, I studied assisted human reproduction as a mechanism of family planning. I noticed that family planning is a right established in the 1988 Federal Constitution, in the 1996 federal Law 9263, and in the 2002 Civil Code. I also noticed that reproductive \& sexual rights are recognized both internationally and nationally. I figured out that, developed to treat infertility, assisted reproduction techniques are currently utilized as instruments of people's parental projects. I also concluded that Brazil still needs specific legislation on this matter.

Keywords: Assisted reproduction; family planning; family law; health law; reproductive rights.

\section{INTRODUÇÃO}

$\mathrm{Na}$ presente investigação, estudaremos como o direito constitucional ao planejamento familiar se manifesta normativamente em relação às técnicas de reprodução assistida. Verificaremos a constitucionalização do projeto parental, os limites ao exercício do referido direito, se existe um direito de acesso à procriação artificial e, por fim, quais as normas infraconstitucionais pertinentes à matéria no ordenamento jurídico brasileiro atual. Nossa pesquisa se justifica em razão de, apesar de o tema ser doutrinariamente recorrente, o legislador permanecer inerte em relação à devida regulamentação da matéria. Por conta dessa omissão legislativa, identificamos o surgimento de correntes doutrinárias conservadoras que,

\footnotetext{
* Bacharel, Mestre e Doutor em Direito pela Universidade Federal da Bahia. Graduate student e pesquisador no Health Law Centre da University of Ottawa. Professor de Direito Civil da Universidade Federal do Oeste da Bahia. 
com base em argumentos há muito ultrapassados, permanecem antipáticas ao amplo acesso à reprodução assistida, buscando restringir o exercício do planejamento familiar por núcleos familiares não-tradicionais.

Utilizaremos o método dedutivo. Estabeleceremos premissas gerais a partir de consulta à doutrina especializada em Direito de Família e em reprodução assistida. Com base nessas premissas, deduziremos as respostas aos questionamentos orientadores da pesquisa. Utilizaremos como marcos teóricos os doutrinadores e as doutrinadoras nacionais que abordam as relações entre Direito de Família e biodireito.

Nosso objetivo geral é verificar se, e em que medida, do direito constitucional ao planejamento familiar decorre um direito de acesso às técnicas de reprodução assistida. Como objetivos específicos, em primeiro lugar analisaremos a constitucionalização do planejamento familiar, bem como a sua regulamentação infraconstitucional e os limites que são impostos ao exercício do referido direito. Em segundo lugar, observaremos como as técnicas de reprodução assistida deixaram de ser encaradas apenas como tratamentos contra a infertilidade e passaram a ser vistas como mecanismos de concretização do planejamento familiar. Em terceiro lugar, identificaremos as normativas infraconstitucionais pertinentes, bem como apontaremos a eventual existência de lacunas legislativas.

\section{CONSTITUIÇÃO FEDERAL DE 1988, FAMÍlIA E PLANEJAMENTO FAMILIAR}

Originalmente, a família apenas era reconhecida pelo ordenamento jurídico brasileiro se constituída por um homem e uma mulher unidos por meio do casamento, um vínculo então indissolúvel. Em um primeiro momento, somente os filhos advindos desta união poderiam ser reconhecidos e desfrutar dos direitos inerentes à filiação. Esse cenário foi se transformando com a edição de uma série de leis que ampliaram as possibilidades de reconhecimento de filhos havidos fora do casamento, bem como permitiram a dissolução da sociedade conjugal e o divórcio. Com o advento da Constituição Federal de 1988, a estrutura do Direito de Família brasileiro sofreu uma verdadeira revolução (RODRIGUES, 1993, p.246). Nesta seara, a primeira grande inovação da Carta de 1988 foi não repetir a previsão das Constituições anteriores, segundo as quais a família seria apenas constituída pelo casamento; o novel constituinte simplesmente afirma, no caput do artigo 226, que a família é a base da sociedade 
e tem especial proteção do Estado. A Constituição Federal de 1988 ampliou o âmbito de proteção das entidades familiares para além do casamento, reconhecendo expressamente a união estável e a família monoparental.

Da mesma forma, do texto constitucional de 1988 depreendem-se diversos princípios relacionados ao Direito de Família, a exemplo da dignidade da pessoa humana, da igualdade entre os cônjuges, da isonomia entre os filhos, da solidariedade familiar, da proteção à criança e ao adolescente, do amparo aos idosos e da proteção ao pluralismo das entidades familiares ${ }^{1}$. Em decorrência dos mencionados princípios, o Direito de Família tem acolhido diversas formas inovadoras de convivência familiar, dando legitimidade social a "modalidades pósmodernas de família", conforme a tese de Adriana Dabus Maluf (2010). Anderson Schreiber (2013, p.313) afirma ser imperativo o reconhecimento de "redes familiares" que não podem "ser encerradas em uma ou outra categoria", trazendo como exemplos as uniões homoafetivas, as "famílias-mosaico", a "família unipessoal", entre diversas outras. Um dos mais significativos princípios constitucionais regentes do Direito de Família é o do livre planejamento familiar, sobre o qual discorreremos na subseção seguinte.

\subsection{A CONSTITUCIONALIZAÇÃO DO PLANEJAMENTO FAMILIAR: PROTEÇÃO À SEXUALIDADE E À REPRODUÇÃO}

Na supramencionada abordagem do ordenamento jurídico acerca das famílias, o artigo 226, $\S 7^{\circ}$ da Constituição Federal de 1988 consagrou o direito ao livre planejamento familiar, fundado nos princípios da dignidade da pessoa humana e da paternidade responsável. Assim, o próprio texto constitucional incumbe o Estado de proporcionar o acesso a recursos educacionais e científicos necessários ao exercício de tal direito.

A previsão constitucional expressa de direito ao planejamento familiar tem relação estreita com o reconhecimento da necessidade de proteção jurídica à sexualidade e à

\footnotetext{
${ }^{1}$ A presente investigação se filia à corrente doutrinária que reconhece na atual ordem constitucional o princípio implícito do pluralismo das famílias. Apresente-se como demonstração jurisprudencial do mencionado princípio a decisão do Supremo Tribunal Federal ao julgar a Ação Direta de Inconstitucionalidade 4277 e a Arguição de Descumprimento de Preceito Fundamental 132, que, a despeito de a literalidade do texto da Constituição Federal de 1988 mencionar apenas a união estável formada pelo homem e pela mulher, foi reconhecida a constitucionalidade da aplicação das regras do referido instituto à união entre casais do mesmo sexo.

CONPEDI LAW REVIEW | EVENTO VIRTUAL | v. 6 | n. 1 | p. 138 - 157 | JAN - DEZ | 2020 
reprodução. A respeito deste tema, Guilherme Calmon Nogueira da Gama (2003, p.444) afirma que o planejamento familiar "se encontra necessariamente relacionado à noção de direitos reprodutivos, assim considerados os direitos básicos vinculados ao livre exercício da sexualidade e da reprodução humana com os limites que lhes são inerentes”. Neste sentido, as Conferências Internacionais do Cairo, de Beijing e de Copenhague reconheceram a importância da saúde reprodutiva e erigiram os chamados "direitos sexuais e reprodutivos" à categoria de direitos humanos (COUTO, 2007, p.50). Na Conferência do Cairo, ficou estabelecido que a saúde reprodutiva implica que "a pessoa possa ter uma vida sexual segura e satisfatória, tenha a capacidade de reproduzir e a liberdade de decidir sobre quando, e quantas vezes o deve fazer". O desdobramento lógico desta condição é a garantia de acesso aos métodos de planejamento familiar. Ainda na Conferência do Cairo, foi assentado que

(...) os direitos de reprodução abrangem certos direitos humanos já reconhecidos em leis nacionais, em documentos internacionais sobre direitos humanos e em outros documentos de acordos. Esses direitos se baseiam no reconhecido direito básico de todo casal e de todo indivíduo de decidir livre e responsavelmente sobre o número, o espaçamento e a oportunidade de seus filhos e de ter a informação e os meios de assim o fazer, e o direito de gozar do mais alto padrão de saúde sexual e de reprodução. Inclui também seu direito de tomar decisões sobre a reprodução, livre de discriminação, coerção ou violência, conforme expresso em documentos sobre direitos humanos. No exercício desse direito, devem levar em consideração as necessidades de seus filhos atuais e futuros e suas responsabilidades para com a comunidade.

Guilherme Calmon Nogueira da Gama (2003, p.712) identifica a existência do direito à reprodução, no âmbito do direito internacional, por força das Declarações Universais e Convenções Internacionais que reconhecem o direito da pessoa a constituir uma família. Gama (2003, p.708-711) ainda constata serem os direitos reprodutivos no âmbito constitucional pátrio decorrentes dos direitos à saúde, à dignidade da pessoa humana e à liberdade. Trata-se "de manifestação dos direitos fundamentais" e, desse modo, essenciais "ao respeito à integridade físico-psíquica da pessoa humana". Por fim, o mencionado autor (2003, p.712) questiona como seria possível implementar o comando constitucional de liberdade no planejamento familiar se não se assegura o próprio direito à reprodução.

Notamos que há corrente doutrinária que equivocadamente rejeita a existência de um direito à reprodução. Nesse sentido, Monica Aguiar (2005, p.91) defende que ter filhos é uma faculdade, não um direito irrestrito, "haja vista que a criança não pode ser vista como instrumento de um direito alheio, sob pena de, por estar a serviço do bem-estar dos pais, 
transmudar-se em coisa e ter valor meramente instrumental". No mesmo sentido se posiciona Eduardo de Oliveira Leite (1995, p.66), segundo quem considerar a procriação como um direito importaria em considerar o futuro filho um simples objeto do desejo dos genitores. Ocorre que, filiados ao supramencionado entendimento de Guilherme Calmon Nogueira da Gama, entendemos que o objeto do direito à procriação não é o filho em si, ou seja, não se confunde com um suposto direito à criança. $\mathrm{Na}$ realidade, o conteúdo dos direitos reprodutivos é a liberdade de decisão a respeito do momento de se conceber a prole e o tamanho desta, bem como a garantia de acesso aos recursos científicos e tecnológicos necessários para exercício do planejamento familiar, nos termos do quanto prevê a já referida Conferência do Cairo.

Aderimos, ainda, ao entendimento de Guilherme Frederico Hernandes Denz (2007, p.15), para quem a Constituição Federal de 1988 prevê implicitamente o direito fundamental à reprodução, decorrente notadamente dos direitos à liberdade, ao planejamento familiar e à saúde. Para o referido pesquisador (2007, p.11), o direito à procriação se manifesta em sentido negativo (impossibilidade de o Estado interferir na liberdade de planejamento familiar do casal) e em sentido positivo (obrigação de o Estado prover todos os instrumentos ao casal para poder conceber). Reiteramos que o conteúdo normativo mencionado não engloba um alegado direito à criança, motivo pelo qual não vinga o equivocado argumento de que se corre o risco de tornar um objeto o futuro ser humano. Maria Claudia Brauner (2003) leciona que a incorporação da sexualidade e da reprodução ao rol de direitos humanos "assegura às pessoas o direito ao planejamento familiar para organização da vida reprodutiva", o que implica na garantia de acesso a todos os recursos científicos que amenizem ou curem patologias ligadas à fertilidade, "desde que considerados seguros e não causadores de riscos aos usuários e usuárias".

\subsection{A DISCIPLINA NORMATIVA DO PLANEJAMENTO FAMILIAR}

Devemos, neste ponto, conceituar o planejamento familiar. Oficialmente, o governo brasileiro (2011) se pronuncia, dizendo que é o "conjunto de ações que auxiliam as pessoas que pretendem ter filhos e também quem prefere adiar o crescimento da família”. Andrea Aldrovandi (2006, p.55), por sua vez, sustenta que se trata da garantia de decidir "o número 
de filhos e o momento mais adequado para o seu nascimento", abrangendo as ações direcionadas à contracepção e à própria concepção.

Regulando o artigo 226, $\S 7^{\circ}$, da Constituição, o legislador positivou o planejamento familiar na Lei no 9263, de 1996, definindo-o como "o conjunto de ações de regulação da fecundidade que garanta direitos iguais de constituição, limitação ou aumento da prole pela mulher, pelo homem ou pelo casal", estabelecendo que se trata de "direito de todo cidadão", sendo "parte integrante do conjunto de ações de atenção à mulher, ao homem ou ao casal, dentro de uma visão de atendimento global e integral à saúde”. Por fim, a Lei 9263/96 ainda determina que "o planejamento familiar orienta-se por ações preventivas e educativas e pela garantia de acesso igualitário a informações, meios, métodos e técnicas disponíveis para a regulação da fecundidade". A respeito da referida Lei, Guilherme Calmon Nogueira da Gama (2003, p.449) afirma que "o texto legal reconhece o recurso às técnicas de fertilização e de concepção para que haja a reprodução humana, o que conduz à constatação de que o direito brasileiro admite o recurso às técnicas conceptivas como inerentes aos direitos reprodutivos das pessoas". Neste mesmo contexto, ao editar o Código Civil de 2002, o Congresso Nacional estabeleceu no artigo $1565, \S 2^{\circ}$ do mencionado diploma legislativo que

o planejamento familiar é de livre decisão do casal, competindo ao Estado propiciar recursos educacionais e financeiros para o exercício desse direito, vedado qualquer tipo de coerção por parte de instituições privadas ou públicas.

Destacamos que, apesar de tal dispositivo estar elencado no capítulo que trata dos efeitos do casamento, este direito não está, de maneira alguma, adstrito às pessoas casadas. Afinal, a já referida Lei 9263/96 assegura o planejamento familiar ao casal, mas também à mulher e ao homem separadamente - em se tratando de norma específica, não foi revogada implicitamente pelo Código Civil, que tem natureza jurídica de lex generalis. Semelhantemente, por haver isonomia axiológica entre todas as diferentes formas de se constituir família, haveria inconstitucionalidade na imposição de limites infraconstitucionais ao planejamento familiar àquelas pessoas unidas pelo vínculo casamentário.

A ideia de planejamento familiar está intimamente relacionada com o "projeto parental", que podemos conceituar como a busca pela constituição de família, especificamente com a geração de descendentes. De acordo com Guilherme Calmon Nogueira da Gama (2003, p.715), “o projeto parental, no mundo contemporâneo, é essencial para as 
famílias, encontrando sua vocação mais autorizada e legítima na época do aumento da família com o nascimento de filhos". O mencionado autor segue afirmando que "a prole proporciona o desenvolvimento da família e sua continuidade". Ressaltamos que planejamento familiar e projeto parental não são expressões sinônimas. Neste sentido, Michelle Couto (2007, p.132) aduz que "a liberdade de fundar uma família pode, mas não de maneira necessária e obrigatória, acarretar na função procriativa", uma vez que há muitas entidades familiares na atualidade que não são constituídas por filhos. O projeto parental não é apenas um reflexo da pulsão natural inerente à função biológica de manutenção da espécie (COUTO, 2007, p.55). De fato, ele se articula com a ideologia dominante na sociedade, sendo influenciado pela religião, pela economia, entre outros (NASCIMENTO, 2009, p.07).

De acordo com Andrea Aldrovandi (2006, p.15), durante muito tempo, a procriação foi considerada como finalidade essencial da família e do casamento. Neste contexto, a paternidade consistia apenas no cumprimento de um dever por parte do homem, com a reafirmação de sua virilidade; a maternidade, por sua vez, seria a maneira através da qual a mulher se tornaria completa. Hodiernamente, vivemos em uma época na qual a sexualidade se desvinculou da procriação, muito em decorrência da popularização dos meios contraceptivos e dos discursos em favor da liberdade sexual. Apesar disso, a sociedade ainda efetua cobranças no sentido de exigir que os casais tenham filhos, em decorrência da valorização da parentalidade (COUTO, 2007, p.66). Em verdade, é intensa a cobrança social a respeito de um projeto parental ameaçado ou frustrado, o que repercute na esfera íntima dos pretensos genitores, podendo causar sentimentos de inferioridade, inveja e angústia. De toda sorte, os paradigmas sociais se transformaram, e o Direito os acompanhou. Atualmente, a parentalidade tem sido encarada como um desígnio que engloba a vida inteira e que deve ter o seu foco direcionado não apenas àqueles que pretendem ser genitores, mas principalmente àquele filho que será gerado (SANCHES, 2012, p.266).

\subsection{A PARENTALIDADE RESPONSÁVEL E O MELHOR INTERESSE DA CRIANÇA E DO ADOLESCENTE}

A Constituição Federal de 1988 garantiu a todos o acesso ao planejamento familiar, todavia tal direito não é absoluto, "pois os direitos da prole e o bem comum impõem seus 
limites" (DINIZ, 2007, 130). Essa limitação consistiria nas "necessidades de seus filhos nascidos e por nascer, bem como seus deveres para com a comunidade”. Conforme já mencionado, o texto constitucional condiciona o planejamento familiar aos princípios da dignidade da pessoa humana e da paternidade responsável.

Sobre a paternidade responsável, em primeiro lugar ressaltamos que o constituinte poderia ter optado por "parentalidade responsável", expressão menos machista e mais inclusiva, que compreende tanto o termo "paternidade" quanto "maternidade". De fato, devemos dar destaque à responsabilidade de ambos os componentes do casal, na medida em que aos dois compete a atitude pró-escolha quanto às consequências das relações sexuais ou da fertilidade assistida (MINAHIM, 1998). Vanessa Berwanger Sandri (2006, p.7) sustenta que a expressão "paternidade responsável" conota tanto a ideia de autonomia para decidir responsavelmente e conscientemente sobre ter ou não filhos, assim como o aspecto da responsabilidade que os pais devem guardar em relação à prole. Valéria Cardin (2009) afirma, por sua vez, que é possível "conceituar a paternidade responsável como a obrigação que os pais têm de prover a assistência moral, afetiva, intelectual e material aos filhos".

De acordo com Vanessa Ribeiro Corrêa Sampaio Souza (2012, p.148), a parentalidade responsável "se cumpre no oferecimento das condições possíveis e necessárias, ainda que de fato não atendam a um rigor ideal de qualidade e satisfação". De acordo com a mencionada doutrinadora (2012, p.149), a responsabilidade dos pais é informada por algumas regras específicas, "mas se sustenta, na verdade, como uma fonte para irradiação de obrigações e cautelas a bem da família, núcleo este gravado à satisfação existencial de seus integrantes”. Para Cristiane Flôres Soares Rollin (2003, p.37), “o fundamento da paternidade responsável reside no empenho pelo bem daqueles em relação aos quais a mesma é exercida, e este empenho está atrelado a um complexo de deveres e direitos correlatos”. Destarte, dos argumentos doutrinários expostos depreendemos que a parentalidade responsável é o princípio que determina que qualquer pessoa que pretenda gerar descendentes amadureça o

\footnotetext{
${ }^{2}$ Com a mesma crítica a respeito do termo "paternidade responsável", sugerindo sua substituição por "parentalidade", cite-se Guilherme Calmon Nogueira da Gama (2003, p.452), para quem "o constituinte disse menos do que queria, provavelmente por ter sido induzido em equívoco diante da tradução do termo 'parental responsability', que, no entanto, possui outra significação no âmbito do direito inglês". Ainda de acordo com o mencionado autor (2003, p.453), "é fundamental que se constate que o termo não se limita ao homem, mas logicamente que se refere também à mulher que, desse modo, terá vários deveres decorrentes das consequências e efeitos jurídicos - no campo da filiação - do exercício dos direitos reprodutivos e sexuais". No mesmo sentido, manifesta-se Mario Antonio Sanches (2012, p.266).

CONPEDI LAW REVIEW | EVENTO VIRTUAL | v. 6 | n. 1 | p. 138 - 157 | JAN - DEZ | 2020 
seu projeto sem pressa, refletindo sobre ele e ponderando a respeito das profundas alterações que sofrerá definitivamente em sua vida.

Indissociável da parentalidade responsável está o chamado princípio constitucional do "melhor interesse da criança e do adolescente"”. Em verdade, a Constituição de 1988 assegura a estes um tratamento absolutamente prioritário, garantindo-lhes a convivência familiar, entre outros direitos, além de colocá-los a salvo da negligência e da discriminação. De acordo com Rodrigo da Cunha Pereira (2012, p.149), o ordenamento jurídico impõe que se preserve ao máximo a pessoa que se encontra em situação de fragilidade; e que a criança e o adolescente "encontram-se nesta posição por estarem em processo de amadurecimento e formação da personalidade" e, por essa razão, "têm posição privilegiada na família, de modo que o Direito viu-se compelido a criar formas viabilizadoras deste intento".

A respeito do melhor interesse da prole, Guilherme Calmon Nogueira da Gama (2003, p.454) sustenta que o homem e a mulher que, no exercício das liberdades inerentes à sexualidade e à reprodução, geram um ser humano têm a responsabilidade individual e social de priorizar o bem-estar físico, psíquico e espiritual desta criança. Por outro lado, Guilherme Calmon Nogueira da Gama (2003, p.718) afirma que a existência dos direitos reprodutivos não significa haver um direito absoluto à criança. De acordo com o referido autor, "não há como reconhecer o direito das pessoas a se socorrer de todos os meios para se ter um filho, mesmo porque do outro lado haverá os interesses e os direitos da futura criança”. Ele ainda ressalta "a importância do Estado na ingerência dessa questão, ao limitar necessariamente o exercício e o próprio conteúdo do direito à reprodução".

Sob essa perspectiva, temos que o exercício dos direitos reprodutivos deve ponderar não apenas a liberdade do casal ou do indivíduo, mas também as consequências advindas da concepção de um novo ser humano. Compreendemos, portanto, que o planejamento familiar igualmente está condicionado e limitado pelo princípio do melhor interesse da criança e do adolescente, na medida em que o projeto parental deverá considerar o filho a ser gerado como prioridade soberana na vida dos pais.

${ }^{3}$ De acordo com Paulo Luiz Netto Lôbo (2008, p.150), a origem do mencionado princípio “é encontrada no instituto inglês do parens patriae como prerrogativa do rei em proteger aqueles que não poderiam fazê-lo em causa própria. Foi recepcionado pela jurisprudência norte-americana em 1813, no caso Commonwealth v. Addicks, no qual a Corte da Pensilvânia afirmou a prioridade do interesse de uma criança em detrimento dos interesses dos pais".

CONPEDI LAW REVIEW | EVENTO VIRTUAL | v. 6 | n. 1 | p. 138 - 157 | JAN - DEZ | 2020 


\section{TECNOLOGIAS REPRODUTIVAS: DE TRATAMENTO DA INFERTILIDADE A INSTRUMENTO DO PLANEJAMENTO FAMILIAR}

Da análise feita até este ponto, observamos que o ordenamento jurídico brasileiro consagra o planejamento familiar e os direitos reprodutivos e sexuais, condicionando-os, porém, a princípios assecuratórios dos interesses da prole gerada e da sociedade como um todo. Igualmente, inferimos que a Constituição Federal de 1988 consagrou a sexualidade e a reprodução como questões de saúde, o que consequentemente as torna direito de todos e dever do Estado.

No contexto da saúde reprodutiva e sexual, devemos destacar a infertilidade, "o nome que se dá às doenças que se traduzem na incapacidade de um casal em gerar filhos" (CARNEIRO, 2005, p.35). A Organização Mundial da Saúde considera infértil um casal que não concebe filhos após um ano de relacionamento sexual sem uso de medidas contraceptivas. Ressaltamos ainda que a infertilidade está listada na Classificação Internacional de Doenças e Problemas Relacionados à Saúde - CID 10, publicada pela Organização Mundial da Saúde. Corrobora-se, portanto, a necessidade de garantias estatais ao seu tratamento.

Ressalvamos que há corrente doutrinária e jurisprudencial defensora da tese de que a infertilidade não é uma patologia, na medida em que todas as demais funções orgânicas do corpo humano podem funcionar saudavelmente independentemente da atividade reprodutora. A este respeito, Carlos Lema Añón (1999, p.170) chama a atenção para o discurso médico que reforça o conceito de necessidade do tratamento da infertilidade. Para o referido autor, a noção de infecundidade enquanto doença é conveniente para os profissionais da saúde, na medida em que cresce a demanda pelos tratamentos reprodutivos. De acordo com Wagner Mota Alves de Souza (2009), “a esterilidade associada a uma ideia negativa é favorável à reserva de mercado". Nesse mesmo sentido, Kátia Maria Straube (2007, p.71) afirma que a infertilidade está longe de ser uma doença, mas se trata de uma vivência nuclear na vida do casal, que traz a impossibilidade de realizar um desejo. Outrossim, há pronunciamentos judiciais negando o custeio, pelo Estado, do tratamento em clínicas especializadas em 
reprodução humana assistida, utilizando como fundamento a inexistência de enfermidade no caso em espécie ${ }^{4}$.

A despeito dos argumentos acima suscitados, depreendemos que não se pode deixar de encarar a infertilidade como patologia, ainda que o restante do organismo humano esteja supostamente em perfeito funcionamento. A despeito de a sociedade aparentemente ter superado o paradigma que subordinava o sexo à reprodução, a infertilidade ainda resulta em “morbidade emocional e problemas interpessoais" (DE LUCA, 2010, p.05), gerando crises psicológicas e mesmo sérios problemas conjugais. De acordo com o Warnock Report (1984, p.08), a falta de filhos pode ser uma fonte de estresse, na medida em que há grande pressão social e expectativas para que o casal "funde uma família" e perpetue os seus genes por mais uma geração, sendo que este desejo específico, que se refere à transmissão do patrimônio genético, não pode ser suprido através da adoção. Eduardo de Oliveira Leite (1995, p.17) ensina que "desde as mais remotas épocas, a esterilidade foi considerada como um fator negativo, ora maldição atribuída à cólera dos antepassados, ora à influência das bruxas, ora aos desígnios divinos”. Em sua tese de doutoramento em Psicologia, Liliana Jacob-Seger (2000, p.07) descreve a experiência da infertilidade como "uma estigmatização, um isolamento e uma alienação". De acordo com a mencionada pesquisadora, as mulheres inférteis se sentem culturalmente rejeitadas e recusadas. Guilherme Calmon Nogueira da Gama (2003, p.661) afirma que a infertilidade enseja problemas como angústia, agressividade ou depressão, e que tais sentimentos comumente extrapolam os limites do casal "para também se estenderem aos familiares, e o fracasso do projeto parental sob a forma natural é motivo de desalinho no desempenho dos papeis do homem e da mulher que a sociedade tradicionalmente estabeleceu".

Conforme demonstrado, apesar de o organismo humano poder subsistir biologicamente independentemente da procriação, a infertilidade interfere diretamente na saúde psicológica das pessoas (e dos casais) que a experimentam. Por essa razão, sustentamos que os problemas de fecundidade devem, sim, ser encarados como questão de saúde, inclusive no que se refere ao acesso a medicamentos e tratamentos. É neste cenário que surgem as técnicas de reprodução assistida, necessárias ao exercício dos direitos constitucionais de planejar livremente a família e de buscar a realização do "projeto parental". De acordo com

\footnotetext{
${ }^{4}$ Cite-se, a título de exemplo, as decisões nos processos 1021693-19.2014.8.26.0071 e 015494652.2008.8.26.0000, ambos do Estado de São Paulo. CONPEDI LAW REVIEW | EVENTO VIRTUAL | v. 6 | n. 1 | p. 138 - 157 | JAN - DEZ | 2020 
Juliane Fernandes Queiroz (2004, p.276), “o intenso desejo de procriação, sempre latente na história da humanidade, impulsionou o desenvolvimento tecnológico para solucionar o problema dos casais inférteis". Conforme Ana Claudia Brandão de Barros Correia Ferraz (2008, p.83), “se se garante o direito de formar uma família, através da concepção natural, há de se reconhecer o direito daqueles que, por razões médicas, não podem procriar naturalmente, a também formarem uma família". Para a referida autora, "o direito a constituir família inclui o direito de procriar, inclusive artificialmente".

Adriana Caldas do Rego Freitas Dabus Maluf (2013, p.193) conceitua a reprodução assistida como a "intervenção do homem no processo de procriação natural, com o objetivo de possibilitar que pessoas com problemas de infertilidade e esterilidade satisfaçam o desejo de alcançar a maternidade ou a paternidade". As mencionadas tecnologias reprodutivas surgiram como mecanismo de tratamento da infertilidade (do casal ou de um deles), "para permitir a efetivação do desejo da paternidade e da maternidade decorrente da própria informação genética de ambos - homem e mulher" (GAMA, 2003, p.636).

As técnicas de concepção assistida configuram uma verdadeira ruptura paradigmática na sociedade, na medida em que abrem espaço para redefinição de conceitos, a exemplo da inovadora ideia de "reprodução sem sexo". A biotecnologia "propiciou a dissociação das etapas reprodutivas do seu ciclo vital, de forma que o coito, a fecundação e a gestação tornaram-se possíveis em local e tempo diversos entre si” (FRAGA; AGUIAR, 2009, p.1.169). Com as alterações socioculturais, notadamente no que se refere à sexualidade, "os direitos reprodutivos passaram a ser encarados não no âmbito do fatalismo da procriação ou da esterilidade, mas como direitos das pessoas à realização pessoal e do casal no âmbito da sociedade" (GAMA, 2003, p.712). Caroline Sátiro de Holanda (2006, p.53) afirma que a tecnologia de procriação artificial ratifica "a livre escolha das pessoas ao planejamento familiar, sendo seu uso uma questão de liberdade e autonomia individual". Dessa forma, podemos afirmar que, atualmente, as técnicas de reprodução assistida são exigidas, necessárias ou utilizadas em situações completamente distintas da infertilidade, como no caso do paciente aidético que quer ter filhos, mas não pode correr o risco numa relação sexual; ou o casal homossexual que não quer se relacionar com alguém do gênero oposto; ou o paciente que irá se submeter a determinado tratamento do qual surge a impotência como efeito colateral (CARNEIRO, 2005, p.39). Como manifestações do planejamento familiar, atualmente já vemos a reprodução assistida ser realizada após a morte do doador do material 
genético (reprodução assistida post mortem); ou com transferência de DNA mitocrondrial para garantir um mínimo vínculo genético entre a mãe registral e a criança concebida por doação de óvulos. Com base nas pesquisas científicas atualmente em estágio avançado, podemos antecipar os próximos passos, que um dia eram considerados impensáveis, de concretização do projeto parental: o desenvolvimento de úteros artificiais e a criação artificial de material genético (sêmen ou óvulos) a partir da derivação in vitro de células-tronco.

Reiteramos que a autonomia reprodutiva não é um direito irrestrito, devendo ser limitada pelos princípios constitucionais asseguradores dos direitos fundamentais dos sujeitos que por ela serão afetados. Diversos países do mundo, preocupados com as consequências (positivas e negativas) das tecnologias reprodutivas, buscaram direcionar sua legislação de forma a garantir que essas técnicas sejam utilizadas com respeito aos direitos humanos de todos os envolvidos - não apenas os genitores, mas também a criança que será gerada. De modo geral, entendemos ser imprescindível o estabelecimento de barreiras legislativas que normatizem as intervenções biocientíficas. Lamentavelmente, o ordenamento jurídico brasileiro carece de leis que regulamentem a reprodução assistida, suas modalidades e a legitimidade para utilizá-las. A ausência de legislação específica enseja insegurança quanto à garantia de acesso por todos às tecnologias reprodutivas - que, conforme vimos, consistem em mecanismo de realização do direito ao planejamento familiar.

De acordo com Mônica Aguiar (2013, p.2), “a omissão legislativa pode gerar, com frequência, distorções em que outros Poderes ou instâncias passem a realizar o papel do legislador". Conforme a mencionada doutrinadora, a inércia do legislador é colmatada por órgãos administrativos, notadamente no que se refere aos problemas que envolvem novas tecnologias. Apesar de nem sempre ser saudável a manutenção dessa lacuna legal, a norma administrativa (emanada, por exemplo, do Conselho Federal de Medicina) "tem o condão de fomentar a discussão para que se possa gerar projetos de lei que venham a suprir a carência de normas legais e contemple amplamente um aspecto da vida cotidiana dos cidadãos", atentando para a discrepâncias sociais e para os reais anseios da sociedade (AGUIAR, 2013, p.3). Na seção seguinte, observaremos o atual estado de coisas sobre a matéria no ordenamento jurídico brasileiro atual.

\section{TRATAMENTO NORMATIVO DADO À REPRODUÇÃO ASSISTIDA NO BRASIL}


Conforme sustentamos até aqui, as técnicas de reprodução assistida são instrumentos úteis e necessários na persecução da concretização do "projeto parental", que é intimamente relacionado com o planejamento familiar, direito consagrado constitucionalmente. A introdução das mencionadas tecnologias no Brasil se deu no início dos anos 1980, quando ainda não havia qualquer regulamentação normativa acerca da matéria; o primeiro bebê de proveta brasileiro foi Anna Paula Caldeira, nascida em outubro de 1984. De acordo com Marco Antonio Zanellato (2004, p.478), "no Brasil, o controle da utilização de técnicas de procriação assistida é basicamente informal, com intervenção mínima do Direito”. Monica Aguiar (2005, p.86) sustenta que, na medida em que as técnicas científicas avançadas são principalmente absorvidas pela parcela da população que detém o poder econômico, a intervenção estatal nessas relações acaba se retardando ainda mais, em decorrência da “equivocada percepção de ser suficiente a regulamentação ética a cargo do Conselho Federal de Medicina ou sob a desculpa de não dever o Estado imiscuir-se em relações privadas entre médicos e pacientes".

Em atenção às inovações científicas no campo reprodutivo, o Conselho Federal de Medicina (CFM), ao editar o Código de Ética Médica (Resolução CFM nº 1246/1988) previu expressamente ser vedado ao médico "desrespeitar o direito do paciente de decidir livremente sobre o método contraceptivo ou conceptivo, devendo o médico sempre esclarecer sobre a indicação, a segurança, a reversibilidade e o risco de cada método". Do mesmo modo, é proibido "praticar fecundação artificial sem que os participantes estejam de inteiro acordo e devidamente esclarecidos sobre o procedimento". No mesmo sentido, o Conselho Federal de Medicina restabeleceu as normas éticas para a utilização das tecnologias de reprodução assistida nas Resoluções 1358/1992, 1957/2010, 2013/2013 e 2121/2015, todas já revogadas. Atualmente, encontra-se em vigor a Resolução nº 2168/2017.

Ocorre que os atos normativos do Conselho Federal de Medicina têm alcance limitado ao âmbito de atuação dos profissionais vinculados à entidade expedidora, qual seja, a comunidade médica. Os referidos preceitos instituem direcionamentos éticos, desprovidos tanto de caráter cogente como de cunho coercitivo para a população em geral. Conforme mencionamos, no ano de 1996, foi editada a Lei ${ }^{\circ}$ 9263/96, que assegurou aos cidadãos o acesso às tecnologias reprodutivas. Tal diploma estipulou que "para o exercício do direito ao planejamento familiar, serão oferecidos todos os métodos e técnicas de concepção e 
contracepção cientificamente aceitos e que não coloquem em risco a vida e a saúde das pessoas, garantida a liberdade de opção". No mesmo ano de 1996, o Conselho Nacional de Saúde, vinculado ao Ministério da Saúde, aprovou a Resolução nº 196, fixando diretrizes e normas regulamentadoras de pesquisas envolvendo seres humanos - entre elas surgem as relacionadas com a reprodução humana. Criou-se a Comissão Nacional de Ética em Pesquisa (CONEP), competente para analisar qualquer projeto que envolva a concepção assistida.

Por fim, o Código Civil de 2002 tratou, superficialmente, a respeito das tecnologias reprodutivas, mencionando-as em somente três incisos do seu artigo 1.597, apenas para presumir como concebidos na constância do casamento os filhos "havidos por fecundação artificial homóloga, mesmo que falecido o marido", os "havidos, a qualquer tempo, quando se tratar de embriões excedentários, decorrentes de concepção artificial homóloga" e os "havidos por inseminação artificial heteróloga, desde que tenha prévia autorização do marido". De acordo com Heloísa Helena Barboza (2004, p.111), é quase impossível pretender disciplinar a reprodução assistida como um todo com sua previsão em apenas três incisos do Código Civil; a autora assevera ainda que, por mais que extensivamente se interpretem tais dispositivos normativos, o que se verifica é que a utilização de técnicas de reprodução assistida "traz uma gama de questões jurídicas que exigem um tratamento em lei especial", na medida em que permanecem inúmeros questionamentos. Giselda Maria Fernandes Novaes Hironaka (2009, p.57) explica tal omissão legislativa pelo fato de que o Código Civil preferiu "deixar a cargo de lei própria e específica a disciplina dos inúmeros pontos de discussão, oriundos da reprodução humana assistida". Tal autora segue afirmando que, enquanto não houver promulgação da legislação específica, os questionamentos e indagações “devem permanecer tratados sob as luzes doutrinárias, e sob o encaminhamento hermenêutico dos dispositivos parcos que tratam - às vezes desastradamente - destas questões”.

No Congresso Nacional, há diversos projetos de lei sobre o tema, a exemplo do Projeto Substitutivo $\mathrm{n}^{\circ}$ 90, de 1999, especificamente direcionado a disciplinar as técnicas de reprodução medicamente assistida. Apesar de tramitar em regime de prioridade, o mencionado Projeto 90/99 aguarda manifestação da Câmara dos Deputados ${ }^{5}$ desde 2003. Atualmente, encontra-se na Comissão de Constituição e Justiça da referida Casa, ainda sem

\footnotetext{
${ }^{5}$ Onde tramita com a numeração PL 1184/2003. Para maiores informações sobre o andamento do mencionado Projeto, sugerimos a consulta ao site oficial da Câmara dos Deputados, utilizando-se tal numeração como parâmetro de pesquisa.

CONPEDI LAW REVIEW | EVENTO VIRTUAL | v. 6 | n. 1 | p. 138 - 157 | JAN - DEZ | 2020 
parecer do Deputado Relator. A última movimentação legislativa foi em 02 de julho de 2019, com designação de novo Relator para o PL (Deputado Diego Garcia, do Podemos do Paraná).

O ordenamento jurídico deve buscar acompanhar a evolução das tecnologias reprodutivas. Contudo, a morosidade do processo legislativo vem impedindo a aprovação dos projetos de lei a este respeito, o que contribui para que muitos aspectos polêmicos permaneçam sem solução jurídica expressamente prevista. Por outro lado, "em lapsos temporais cada vez mais exíguos, surgem novas técnicas médicas que se sucedem em seus complementos", que acabam se confrontando "com o mundo jurídico e seu aparato conceitual pré-constituído, revelando total inadequação em formular respostas às questões emergentes" (QUEIROZ, 2004, p.271). Da mesma forma, os desdobramentos de tais avanços científicos são inúmeros, o que claramente enseja cada vez mais profundos dilemas éticos e jurídicos. Especificamente sobre a reprodução assistida, Silvia da Cunha Fernandes (2005, p.05) afirma que "a dinâmica desse progresso atropelou, bruscamente, a reflexão ética e algumas sólidas instituições jurídicas”. De acordo com Rolf Madaleno (2013, p.523), como a lei não fornece as respostas para as indagações complexas decorrentes da procriação humana assistida, a Bioética deve ocupar "espaço no âmbito do Direito de Família, com um longo caminho a ser percorrido para normatizar os procedimentos médicos de manipulação genética e a conduta humana na manipulação dessas novas e importantes descobertas". Por outro lado, Dirce Guilhem e Mauro Machado do Prado (2001, p.120) chamam a atenção para a ausência quase total da Bioética nas discussões legislativas a respeito das técnicas de reprodução artificial, o que demonstra que questões importantes relacionadas à saúde sexual e reprodutiva "não têm merecido uma discussão ampliada no que se refere às diferentes moralidades que permeiam a sociedade brasileira".

Em resumo, observamos que as técnicas de reprodução assistida atualmente são importante instrumento de concretização do direito ao planejamento familiar. Nascidas com foco no tratamento da infertilidade, hoje em dia são também bastante utilizadas como mecanismo de implementação do projeto parental. Por conta de seu potencial de romper paradigmas, a reprodução assistida deveria ser objeto de tratamento legislativo, para que se estabeleçam os critérios de permissão, proibição e regulamentação das diferentes tecnologias reprodutivas. No Brasil, o legislador inadequadamente não tem desempenhado esse papel, cabendo ao Conselho Federal de Medicina suprir essa lacuna legislativa. Apesar de o processo de elaboração da norma administrativa ser mais flexível, especializado e hábil para atender às 
constantes novidades no campo da procriação artificial, acreditamos que faltam às Resoluções do CFM a legitimidade democrática e o caráter vinculante erga omnes que teria uma lei em sentido estrito.

Como regulamentação específica do direito constitucional ao planejamento familiar, defendemos a edição de um Estatuto da Reprodução Humana Assistida. Essa lei deve fundamentar um microssistema, no qual se preveem normas de naturezas distintas. Em matéria cível, ilustrativamente devem ser tratadas questões de capacidade e do consentimento para se submeter às tecnologias reprodutivas; da responsabilidade civil decorrente dos procedimentos; da natureza juris-real ou obrigacional do contrato de conservação do material genético; dos vínculos familiares e sucessórios; do sistema de registros públicos (para garantir que famílias não-heternormativas possam sem dificuldade registrar os seus filhos concebidos por reprodução assistida); do anonimato do doador do material genético em se tratando de reprodução heteróloga etc. Também devem ser abordadas questões de natureza penal, administrativa e processual. Damos especial destaque à positivação da obrigação estatal de custear o acesso ao procedimento via rede pública de saúde, com critérios objetivos de elegibilidade e preferência, para assegurar que o exercício desse direito não fique ao sabor de políticas públicas arbitrárias.

\section{CONCLUSÃO}

No presente artigo, observamos que a reprodução assistida é um dos mecanismos de concretização do direito constitucional ao planejamento familiar. Contudo, igualmente notamos que se faz devido o tratamento da matéria pelo ordenamento infraconstitucional brasileiro.

Notamos que a Constituição Federal de 1988 previu expressamente o direito ao planejamento familiar. Verificamos também que tal direito deve ser exercido livremente, porém não ilimitadamente, na medida em que condicionado a outros valores constitucionalmente relevantes - especificamente a dignidade da pessoa humana, a parentalidade responsável e o melhor interesse da prole.

Compreendemos que as tecnologias de reprodução assistida surgiram como mecanismos de tratamento contra a infertilidade. Também percebemos que, atualmente, as CONPEDI LAW REVIEW | EVENTO VIRTUAL | v. 6 | n. 1 | p. 138 - 157 | JAN - DEZ | 2020 
técnicas reprodutivas artificiais não se limitam a tais casos, sendo especialmente importantes para a concretização do planejamento familiar. Apesar das correntes doutrinárias em sentido contrário, depreendemos que a saúde reprodutiva é um direito inerente ao ser humano, relacionado ao projeto parental de cada indivíduo. Nesse sentido, percebemos ser equivocado o argumento de que reconhecer a reprodução como um direito significaria instrumentalizar a criança; concluímos que o direito é às técnicas reprodutivas, não à criança.

Percebemos que, se por um lado a reprodução assistida é importante instrumento a favor do planejamento familiar, por outro lado suas consequências para a vida humana e para o direito tornam imprescindível o seu devido tratamento pelo legislador. Entretanto, depreendemos que, no Brasil, a ampla maioria das normas jurídicas abstratas a respeito da procriação artificial têm sido editadas pelo Conselho Federal de Medicina. Apesar dos méritos de tais normativas administrativas, compreendemos que a elas faltam a legitimidade democrática e o caráter vinculante erga omnes de leis em sentido estrito. Por essa razão, como forma de regulamentação infraconstitucional do direito ao planejamento familiar por meio da procriação artificial, concluímos pela necessidade de edição de um Estatuto da Reprodução Asssistida - um microssistema com normas cíveis, penais, administrativas e processuais que disponham, na medida do possível, sobre a proibição, a permissão e a regulamentação das tecnologias procriacionais e das inúmeras consequências da sua utilização.

\section{REFERÊNCIAS}

AGUIAR, Monica. Direito à filiação e bioética. Rio de Janeiro: Forense, 2005.

AGUIAR, Monica. Modelos de autonomia e sua (in)compatibilidade com o sistema de capacidade civil no ordenamento positivo brasileiro: reflexões sobre a resolução 1995/2012 do Conselho Federal de Medicina. 2013. Disponível em: http:// http://www.publicadireito.com.br/artigos/?cod=69c7e73fea7ad35e. Acesso em 10 de maio de 2016.

ALDROVANDI, Andrea. $\mathbf{O}$ acesso às tecnologias reprodutivas: garantias e limites jurídicos. 2006. Dissertação (Mestrado em Direito) - Faculdade de Direito, Universidade de Caxias do Sul, Caxias do Sul, 2006.

AÑón, Carlos Lema. Reprodución, Poder y Derecho. Ensayo filosófico - jurídico sobre las técnicas de reprodución assistida. Madrid: Trotta, 1999. 
BARBOZA, Heloisa Helena. As relações de parentesco no Novo Código Civil. In: Revista da EMERJ, número Especial: Anais do Seminário EMERJ Debate o Novo Código Civil, parte II, 2004. Disponível em:

http://www.emerj.tjrj.jus.br/revistaemerj_online/edicoes/anais_onovocodigocivil/anais_especi al_2/Anais_Parte_II_revistaemerj_107.pdf. Acesso em 17 de novembro de 2015.

BRAUNER, Maria Claudia. Novas tecnologias reprodutivas e projeto parental: contribuição para o debate no Direito Brasileiro. Texto incluído em 07/03/2003. Disponível em: < http://www.ufrgs.br/bioetica/repbrau.htm>. Acesso em 10 de outubro de 2014.

CARDIN, Valéria Silva Galdino. Do planejamento familiar e da paternidade responsável na reprodução assistida. Trabalho publicado nos Anais do XVIII Congresso Nacional do CONPEDI, realizado em São Paulo - SP nos dias 04, 05, 06 e 07 de novembro de 2009. Disponível em: http:// www.publicadireito.com.br/conpedi/manaus/arquivos/Anais/sao_paul o/2409.pdf. Acesso em 20 de setembro de 2014.

CARNEIRO, Valnêda Cássia Santos. Filiação e Biotecnologia: questões novas na tutela jurídica da família. 2005. Dissertação (Mestrado em Família na Sociedade Contemporânea) - Faculdade de Direito, Universidade Católica do Salvador; Salvador, 2005.

COUTO, Michelle Cristine Assis. Existe um direito de ter filhos? 2007. Dissertação (Mestrado em Direito Privado) - Faculdade de Direito, Universidade Federal da Bahia, Salvador, 2007.

DE LUCA, Caterina. O concebido post mortem no Direito das Sucessões. Texto incluído em 2010. Disponível em

http://www.emerj.tjrj.jus.br/paginas/trabalhos_conclusao/2semestre2010/trabalhos_22010/cat erinaluca.pdf. Acesso em 09 de outubro de 2014.

DENZ, Guilherme Frederico Hernandes. Procriação assistida e direito à saúde: análise do planejamento familiar à luz do princípio da dignidade da pessoa humana e da primazia do direito da criança. 2007. Dissertação (Mestrado em Direito) - PUC/PR, Curitiba, 2007.

DINIZ, Maria Helena. O estado atual do biodireito. São Paulo: Saraiva, 2007.

FERNANDES, Silvia da Cunha. As técnicas de reprodução humana assistida e a necessidade de sua regulamentação jurídica. Rio de Janeiro: Renovar, 2005.

GAMA, Guilherme Calmon Nogueira da. A nova filiação: o biodireito e as relações parentais. Rio de Janeiro: Renovar, 2003.

GUILHEM, Dirce; PRADO, Mauro Machado do. Bioética, legislação e tecnologias reprodutivas. Revista Bioética, vol.09, nº2, 2001.

HIRONAKA, Giselda Maria Fernandes Novaes. As inovações biotecnológicas e o direito das sucessões. Revista Jurídica: órgão nacional de doutrina, jurisprudência, legislação e crítica judiciária. Ano 57, nº 375, janeiro de 2009. 
LEITE, Eduardo de Oliveira. Procriações artificiais e o direito: aspectos médicos, religiosos, psicológicos, éticos e jurídicos. São Paulo: Editora Revista dos Tribunais, 1995.

MADALENO, Rolf. Curso de direito de família. $5^{\text {a }}$ ed. Rio de Janeiro: Forense, 2013.

MALUF, Adriana Caldas do Rego Freitas Dabus. Novas modalidades de família na pósmodernidade. 2010. Tese (Doutorado em Direito Civil) - Faculdade de Direito, Universidade de São Paulo, São Paulo, 2010. Disponível em: http://

www.teses.usp.br/teses/disponiveis/2/2131/tde-31012011-154418/. Acesso em 29 de setembro de 2014.

MINAHIM, Maria Auxiliadora. Direitos reprodutivos e sexuais; constituição e efetivação da cidadania. Revista Jurídica dos Formandos em Direito da UFBA, Salvador, v.3, n.4 , p.143-150, jul./dez. 1998.

NASCIMENTO, Fátima Regina Mibach do. Adiamento do projeto parental: um estudo psicológico com casais que enfrentam a esterilidade. 2009. Dissertação (Mestrado em Psicologia) - Faculdade de Psicologia da Pontifícia Universidade de Campinas. Campinas, 2009.

PEREIRA, Rodrigo da Cunha. Princípios fundamentais norteadores do direito de família. 2. Ed. São Paulo: Saraiva, 2012.

QUEIROZ, Juliane Fernandes. A disponibilidade do material genético - sêmen - após a morte do seu titular. In: CASABONA, Carlos María Romeo; QUEIROZ, Juliane Fernandes (coord.). Biotecnologia e suas implicações ético-jurídicas. Belo Horizonte: Del Rey, 2004.

RODRIGUES, Silvio. Breve histórico sobre o direito de família nos últimos 100 anos. Revista da Faculdade de Direito, Universidade de São Paulo, [S.1.], v. 88, p. 239254, jan. 1993. ISSN 2318-8235. Disponível em: http://www.revistas.usp.br/rfdusp/article/view/67221. Acesso em: 19 de novembro de 2015.

ROLLIN, Cristiane Flôres Soares. Paternidade Responsável em direção ao melhor interesse da criança. In: PORTO, Sérgio Gilberto; USTÁRROZ, Daniel (org). Tendências constitucionais no Direito de Família: estudos em homenagem ao Prof. José Carlos Teixeira Giorgis. Porto Alegre: Livraria do Advogado Editora, 2003.

SANCHES, Mario Antonio. Reprodução assistida: da parentalidade à metaparentalidade. In: PORTO, Dora; GARRAFA, Volnei; MARTINS, Gerson Zafalon; BARBOSA, Swenderberger do Nascimento. Bioéticas, poderes e injustiças: 10 anos depois. Brasília: CFM/Cátedra Unesco de Bioética/SBB, 2012.

SANDRI, Vanessa Berwanger. Princípio jurídico da paternidade responsável: distinção entre planejamento familiar e controle da natalidade. Monografia (Graduação em Direito) - Faculdade de Direito da Pontifícia Universidade Católica do Rio Grande do Sul, Porto Alegre, 2006.

SCHREIBER, Anderson. Direito civil e constituição. São Paulo: Atlas, 2013. 